\title{
INTENSITY-DURATION-FREQUENCY RATIOS OBTAINED FROM ANNUAL RECORDS AND PARTIAL DURATION RECORDS IN THE LOCALITY OF PELOTAS - RS, BRAZIL
}

\section{CLAUDIA F. A. TEIXEIRA ${ }^{1}$, RITA DE C. F. DAMÉ ${ }^{2}$, JOSÉ L. C. ROSSKOFF ${ }^{3}$}

\begin{abstract}
The intensity-duration-frequency occurrence ratio (IDF) is a tool commonly used for precipitation-runoff data transformation, which is established from observations of intense precipitations over a period sufficiently long as to allow the occurrence of extremes at the observation site. This study focused on verifying the existence or absence of new data, in terms of IDF ratio, by using partial duration records produced from data on maximum daily disaggregated rainfall for pre determined durations. The partial duration records considered a base value of 55 $\mathrm{mm}$, totaling 279 values. After the rainfall series were established, their independence and seasonality were assessed. Using the Student's $t$-test statistics, it was established that no new data, as IDF ratio, emerged from the analysis of the partial duration series with the recommended base value of precipitation, as compared to the historical records.
\end{abstract}

KEYWORDS: maximum rainfall, daily disaggregated precipitation, probability models.

\section{RELAÇÕES INTENSIDADE-DURAÇÃO-FREQUÊNCIA OBTIDAS A PARTIR DE SÉRIES ANUAL E DE DURAÇÃO PARCIAL PARA A LOCALIDADE DE PELOTAS-RS}

RESUMO: A relação intensidade-duração-frequência de ocorrência (IDF) é uma ferramenta utilizada nos processos de transformação chuva-vazão, e sua determinação deve ser obtida a partir de observações de chuvas intensas, durante um período de tempo longo e representativo dos eventos extremos do local. O presente trabalho teve como objetivo verificar a existência ou não de ganho de informação, em termos de relação IDF, ao serem utilizadas séries de duração parcial, a partir dos dados de chuva máxima diária desagregada, em durações preestabelecidas. Quanto à série de duração parcial, foi utilizado o valor-base preestabelecido de $55 \mathrm{~mm}$, constituindo então 279 valores. Posteriormente à constituição das séries de chuva, foi avaliada a independência e a estacionaridade dos valores contidos nas mesmas. Pela metodologia do teste " $t$ " de Student, constatou-se que não há ganho de informação em termos de relação IDF quando utilizada a série de duração parcial, com o valor-base preestabelecido de precipitação, comparativamente à série de registros históricos.

PALAVRAS-CHAVE: chuva máxima, desagregação de chuva diária, modelos probabilísticos.

\section{INTRODUCTION}

Rain is considered a random event and for its characterization, it is necessary to know the duration, intensity and frequency of its occurrence or return time (Tr). This relationship is commonly referred to as intensity-duration-frequency of occurrence (IDF), being a tool used in the processes of rainfall-runoff transformation (DAMÉ et al., 2008).

The determination of the IDF relationship must be taken from observations of heavy rain over a long and representative period of extreme local events. To compile the rainfall series for statistical

\footnotetext{
${ }^{1}$ Eng $^{\mathrm{a}}$ Agrícola, Prof. Adjunto, Centro de Engenharias, Universidade Federal de Pelotas,. Caixa Postal 354,. Fone: (53) 3275-7165, cfteixei@ig.com.br.

${ }^{2}$ Eng $^{\mathrm{a}}$ Agrícola, Prof. Associada, Centro de Engenharias, Universidade Federal de PelotasCaixa Postal 354, Fone: (53) 3275-7165, ritah2o@hotmail.com.

${ }^{3}$ Eng $^{\mathrm{o}}$ Agrícola, Prof. Associado, Centro de Engenharias, Universidade Federal de Pelotas, Caixa Postal 354, Fone: (53)3275-7165, rosskoff@ufpel.edu.br.

Recebido pelo Conselho Editorial em: 11-11-2009
}

Aprovado pelo Conselho Editorial em: 24-5-2011

Eng. Agríc., Jaboticabal, v.31, n.4, p.687-694, jul./ago. 2011 
analysis, two ways can be taken: the establishment of an annual or a partial duration series. The annual series is made of the highest value within each calendar or hydrological year, and the partial duration series is composed of data, whose values exceed a predetermined base value, no matter the frequency of occurrence of these values within each year (SANSIGOLO, 2008). The use of the annual series is of current use, since it is easily obtained, even without the establishment of a predetermined base value, as required for the partial duration series (BEGUERÍA, 2005). Regarding the determination of base constitution value of the partial duration series, BEN-ZVI (2009) reported that there are no standardized rules, i.e., it depends on each case in study.

In relation to studies of heavy rains that used partial duration series, there are only a few studies and, in these the criterion for choosing the base constitution value for the formation of the series does not follow a common rule. In this sense, the work by BELL (1969) used, as the criterion for the baseline to compose the series, was rains with return period of 2 years and hourly duration. The author also considered the possibility of estimating IDF relationships in places where data is only available from rain gauge by using the maximum mean annual rainfall with daily duration, and the mean number of days with storm. In MADSEN et al. (1997), the partial duration series for all stations in the region studied were made using an average of 2.5 to 3.2 events for each year analyzed. SVENSSON et al. (2007) used as base value rain greater than or equal to $7.7 ; 12.3 ; 16$ and $24 \mathrm{~mm}$ for durations of $1 ; 2 ; 3$ and 6 hours, respectively.

To estimate the IDF relationship for the city of Pelotas, in the state of Rio Grande do Sul (RS), southern Brazil, GOULART et al. (1992) used a series of partial duration over a period of 25 years, and as baseline, rain with less than $20 ; 23 ; 25 ; 28 ; 30 ; 35 ; 38 ; 4450$ and $55 \mathrm{~mm}$ for the durations of $30 ; 45 ; 60 ; 90 ; 120 ; 240 ; 360 ; 720 ; 1,080$ and 1,440 minutes, respectively (DAMÉ et al., 2005).

Another aspect to consider is the scant availability of rain gauge records and the abundance of rainfall data. Given this reality, we must develop methodologies to estimate IDF relationships, which are used in the rainfall-runoff transformation process for sites that only have rainfall data. For this, one of the alternatives is to use a data set of annual maximum daily precipitation that is representative, stationary and homogeneous (BRUSA, 2004) with the intention of, from this, obtaining rain heights at sub-daily intervals (DAMÉ et al., 2007). By obtaining daily precipitation data, associated with interest return periods, one can use appropriate disaggregation methods. Thus, the relationship between precipitation heights, depending on the disaggregation duration and return period, IDF relationships are originated from precipitation records.

The disaggregation technique, which is currently used in engineering, is based on the disaggregation coefficients (DAEE-CETESB, 1979). In this sense, the study by ROBAINA \& CHEST (1992) aimed at testing the performance of a disaggregation model of heavy rains in order to generate maximum average rainfall during less than 24 hours. There are also methods that involve precipitation simulation in sub-hourly duration, and the association of the series of simulated stochastic disaggregation (COWPERTWAIT, 2006; DAMÉ et al., 2007), to allow obtaining IDF relationships.

This study aimed at verifying the possibility of information gain in terms of IDF relationship when using annual and partial duration series, with maximum daily disaggregated rainfall compared to historical values of rain intensities with data from the city of Pelotas - RS, Brazil.

\section{MATERIAL AND METHODS}

This study used rainfall data during the period between 1921 to 2008 registered for the town of Pelotas/RS, and obtained at the Agroclimatology Station - EMBRAPA Collaboration / UFPel, INMET $\left(31^{\circ} 51^{\prime} \mathrm{S} ; 52^{\circ} 21^{\prime} \mathrm{W}\right.$; at $13.2 \mathrm{~m}$ altitude). According to the Koeppen's classification, the local climate is subtropical (or almost temperate), moist without dry period, with an average annual rainfall of 1,366.9 $\mathrm{mm}$, with February with the highest precipitation, $188.2 \mathrm{~mm}$, and October with the lowest rainfall, $74.7 \mathrm{~mm}$. As for the temperature, the hottest month is January, exceeding $22{ }^{\circ} \mathrm{C}$, 
and July is the coldest month, with less than $18{ }^{\circ} \mathrm{C}$ and above $3{ }^{\circ} \mathrm{C}$. The average monthly temperatures are between $10^{\circ} \mathrm{C}$ and $22^{\circ} \mathrm{C}$.

From the daily rainfall database, two series were established with annual or partial duration data. To compose the annual series, the highest daily rainfall value was extracted from each year analyzed, resulting in a total of 88 values. As for the partial duration series, it was used the preestablished baseline of $55 \mathrm{~mm}$ (GOULART et al., 1992), resulting in a series of 279 values. After the formation of the rainfall series, the independence and stationarity parameters of the values contained in the series were evaluated. To check the independence of the maximum daily rainfall, the sample autocorrelation function was used (Groppo et al., 2005), and for the stationarity of the series, the nonparametric Mann-Kendall was employed (RODRIGUES \& SANTOS, 2007).

We adjusted the Log-Normal probability models with two parameters, Gumbel and LogPearson III, by using the maximum likelihood method (MELLO \& SILVA, 2005; LONG et al., 2006). After adjusting the parameters of the probabilistic models, the model that best fit the values of maximum intensity of rainfall was selected by using the Kolmogorov-Smirnov test.

In order to obtain the IDF relationship from rainfall records, we applied the relation method (DAEE-CETESB, 1979; OLIVEIRA et al., 2005) to disaggregate the daily rainfall. We initially obtained disaggregation coefficients from the relationship between the precipitation values with different durations $(15 ; 30 ; 60 \mathrm{~min}$, and $1 ; 6 ; 12$ and $24 \mathrm{~h})$ and the various return periods $(2 ; 5 ; 10$; 20; 50 and 100 years), and the rain gauge records in the same duration and return periods studied (SILVEIRA, 2000). Thus it was obtained disaggregation coefficients of daily rainfall durations in $24 \mathrm{~h} / 1$ day, $12 \mathrm{~h} / 24 \mathrm{~h}, 6 \mathrm{~h} / 24 \mathrm{~h}, 1 \mathrm{~h} / 24 \mathrm{~h}, 30 \mathrm{~min} / 1 \mathrm{~h}$, and $15 \mathrm{~min} / 30 \mathrm{~min}$, and consequently, rainfall heights, resulting in IDF relationships from rainfall data.

The rainfall intensity-duration-frequency relations were represented by equations as following (BORG et al. 2005; SILVA et al., 2006):

$$
\mathrm{I}=\frac{\mathrm{KT}_{\mathrm{r}}^{\mathrm{m}}}{(\mathrm{t}+\mathrm{b})^{\mathrm{n}}}
$$

where,

$\mathrm{I}$ - rainfall intensity, $\mathrm{mm} \mathrm{h}^{-1}$;

$\operatorname{Tr}$ - return period, years;

$\mathrm{t}$ - rainfall duration, min, and

$\mathrm{K}, \mathrm{m}, \mathrm{b}, \mathrm{n}$ - parameters of the equation that must be adjusted to observed data.

The estimation of the equation parameters of heavy rainfall was carried out by non-linear multiple regression (MELLO \& SILVA, 2005), in which the value of $b$ was obtained by a regression between the maximum rain intensities, with a given return period $(\mathrm{Tr}=20$ years for the annual series, $\operatorname{Tr}=50$ years for the partial duration series), and the values of $(t+b)$ for different values of $\mathrm{b}$. The coefficients $\mathrm{K}$ and $\mathrm{m}$ were estimated by linear regression using logarithmic transformation, considering the relation $\mathrm{C}=\mathrm{K} \mathrm{Tr} \mathrm{T}^{\mathrm{m}}$. The equations obtained from the annual and partial duration series were compared with rain gauge records for the period from 1982 to 1998, for durations of $15 ; 30 ; 60 ; 360 ; 720$ and 1,440 minutes, and return periods of 2; 5; and 10 years (DAMÉ et al., 2008).

To assess if there was or there was no significant difference, at $\alpha$ probability level, between the intensity values obtained from the annual and the partial duration series compared to the historical values of rain intensities in the city of Pelotas - RS, the Student's $t$-test for the linear and angular coefficients $\left(Y=\beta_{0}+\beta_{1} \mathrm{X}\right)$ was used. The null hypothesis $\left(\mathrm{H}_{0}\right)$ was tested with the $t$-test for the linear, $\beta_{0} ; \mathrm{H} 0: \beta_{0}=1$ and the angular; $\beta_{1} ; \mathrm{H} 0: \beta_{1}=0$ coefficients. Therefore, if the calculated statistic test is above the critical value for a level of probability $(1-\alpha / 2)$, being $\alpha=5 \%, \mathrm{H}_{0}$ is rejected, and there is relation between the values of intensities maximum obtained from the tested series. 


\section{RESULTS AND DISCUSSION}

The results of the verification of independence of the annual and partial duration series show that they are independent, since the values of sample correlation coefficient for annual series $\left(\mathrm{r}_{\mathrm{k}}=\right.$ 0.036) was lower than the critical correlation coefficient $\left(r_{\text {crit }}=2126\right)$, as well as for the partial duration series $\left(r_{k}=-0.0215 ; r_{c r i t}=0.1179\right)$. As for stationarity, the values found for $Z_{m k}$ were 0.056 (annual) and 0.024 (partial duration), being lower than the critical value, $\mathrm{Z}_{\alpha}$, which equals to 3.29 for a confidence interval of $99 \%(\alpha=1 \%)$. Since the Mann-Kendall statistical values were positive in both scenarios, it appears that there was an increase in the rainfall; however, it is not possible to determine from this analysis the magnitude of this increase (SOUZA et al., 2009).

Table 1 shows the Kolmogorov-Smirnov statistical test $\left(D_{\max }\right)$ values for the three adjusted probability distributions. It is observed that the Gumbel and Log-Normal distributions did not fit properly the partial duration series, since the $D_{\max }$ values were higher than the $D_{\text {crit, }}$, which is 1.628 for the significance level of $1 \%$. The Log-Pearson III distribution was the one that best fit the sample data sets of both, annual and partial duration, since the calculated statistical value was lower than the critical value $(1.628, \alpha=1 \%)$. In the work described by ARON et al. (1987), the authors determined several heights of rainfall lasting from 1 to $24 \mathrm{~h}$, and return periods ranging from 1 to 100 years in the State of Pennsylvania (USA), and observed that the Log-Pearson Type III distribution showed better adjustment. However, there is no consensus regarding the most appropriate probability distribution to adjust the maximum daily rainfall data. When investigating the robustness of several probability distributions used in the analyses of extreme hydrological events, BACK (2006) and SANSIGOLO (2008) found that the Gumbel distribution was better adjusted to the maximum daily rainfall values.

TABLE 1. Calculated values $\left(\mathrm{D}_{\max }\right)$ of the Kolmogorov-Smirnov test for the adjusted distributions of probability to the annual series and of partial duration of daily maximum rain of Pelotas/RS, in the period from 1921 to 2008.

\begin{tabular}{lcc}
\hline \multicolumn{1}{c}{ Probability Distribution } & \multicolumn{2}{c}{$\mathrm{D}_{\max }$} \\
\cline { 2 - 3 } & Annual & Partial Duration \\
\hline Gumbel & 6.05 & 1.976 \\
Log-Normal & 0.88 & 1.976 \\
Log-Pearson III & 0.65 & 1.536 \\
\hline $\mathrm{D}_{\text {crit }}=1.628$ for the significance level of 1\%. &
\end{tabular}

Table 2 shows the parameters of scale $(\xi)$ and shape $(\alpha, \beta)$ of the density function of the LogPearson III distribution, adjusted to the annual and partial duration series, that were used to estimate maximum daily rainfall for return periods of $2 ; 5 ; 10 ; 20 ; 50$ and 100 years of the city of Pelotas/RS. The estimation values for the maximum daily rainfall are shown in Table 3.

TABLE 2. Parameters of the Log-Pearson III distribution fitted to the annual series and of partial duration of daily maximum rain of Pelotas-RS, in the period from 1921 to 2008.

\begin{tabular}{crc}
\hline \multirow{2}{*}{ Parameters } & \multicolumn{2}{c}{ Series } \\
\cline { 2 - 3 } & Annual & Partial Duration \\
\hline$\xi$ & 3.097 & 3.840 \\
$\beta$ & 18.459 & 3.226 \\
$\beta$ & 0.073 & 0.139 \\
\hline
\end{tabular}

Disaggregation coefficients of daily rainfall determined for the city of Pelotas-RS, which values represent the relation of rainfall heights for the durations of $24 \mathrm{~h} / 1$ day, $12 \mathrm{~h} / 24 \mathrm{~h}, 1 \mathrm{~h}$ and $6 \mathrm{~h} / 24 \mathrm{~h} / 24 \mathrm{~h}, 30 \mathrm{~min} / 1 \mathrm{~h} 15 \mathrm{~min} / 30 \mathrm{~min}$, are shown in Table 4. Moreover, the coefficients in current use in hydrological studies in Brazil are also presented (DAMÉ et al., 2010). 
TABLE 3. Values of daily maximum rain $(\mathrm{mm})$ obtained by the fit of the distribution of LogPearson III probability to the annual series and of partial duration of Pelotas-RS.

\begin{tabular}{ccccccc}
\hline \multirow{2}{*}{ Series } & \multicolumn{7}{c}{$\operatorname{Tr}$ (years) } \\
\cline { 2 - 6 } & 2 & 5 & 10 & 20 & 50 & 100 \\
\hline Annual & 82.51 & 108.81 & 127.55 & 146.56 & 172.84 & 193.93 \\
Partial Duration & 69.85 & 87.98 & 102.16 & 117.47 & 140.08 & 159.35 \\
\hline
\end{tabular}

The estimated disaggregation coefficients for the city of Pelotas-RS are very close to the national values, but it is worth mentioning that the value equals the national average $(0.70)$ for the shortest duration tested (15 min). For the durations of $24 \mathrm{~h} 30 \mathrm{~min}$, the percentage differences between local and national values are underestimated in 17.5 and $7 \%$, respectively. For other durations $(12 ; 6$ and $1 \mathrm{~h})$, the percentage differences are overestimated in 9; 18 and $14 \%$ respectively. In order to adjust equations relating rainfall of different durations to Urussanga-SC (State of Santa Catarina, southern Brazil), BACK (2009) found a disaggregation coefficient of 1.13 for the ratio of maximum rainfall of $24 \mathrm{~h}$ and daily.

TABLE 4. Disaggregation coefficients of rainfall data for the relationships $24 \mathrm{~h} / 1$ day; $12 \mathrm{~h} / 24 \mathrm{~h}, 6$ $\mathrm{h} / 24 \mathrm{~h}$ and $1 \mathrm{~h} / 24 \mathrm{~h} ; 30 \mathrm{~min} / 1 \mathrm{~h}$ and $15 \mathrm{~min} / 30 \mathrm{~min}$ and periods of return of 2; 5; $10 ; 20 ; 50$ and 100 years.

\begin{tabular}{|c|c|c|c|c|c|c|c|c|}
\hline \multirow{3}{*}{ Relation } & \multicolumn{7}{|c|}{ Pelotas-RS } & \multirow{3}{*}{$\begin{array}{l}\text { National } \\
\text { Average }\end{array}$} \\
\hline & \multicolumn{7}{|c|}{$\operatorname{Tr}$ (years) } & \\
\hline & 2 & 5 & 10 & 20 & 50 & 100 & Average & \\
\hline $24 \mathrm{~h} * / 1$ day** & 0.94 & 0.96 & 0.97 & 0.98 & 0.99 & 0.99 & 0.97 & 1.14 \\
\hline $12 \mathrm{~h} / 24 \mathrm{~h}$ & 0.90 & 0.92 & 0.93 & 0.94 & 0.94 & 0.95 & 0.93 & 0.85 \\
\hline $6 \mathrm{~h} / 24 \mathrm{~h}$ & 0.79 & 0.83 & 0.85 & 0.86 & 0.87 & 0.88 & 0.85 & 0.72 \\
\hline $1 \mathrm{~h} / 24 \mathrm{~h}$ & 0.47 & 0.47 & 0.48 & 0.48 & 0.48 & 0.49 & 0.48 & 0.42 \\
\hline $30 \mathrm{~min} / 1 \mathrm{~h}$ & 0.76 & 0.72 & 0.70 & 0.68 & 0.67 & 0.66 & 0.69 & 0.74 \\
\hline $15 \mathrm{~min} / 30 \mathrm{~min}$ & 0.71 & 0.70 & 0.70 & 0.70 & 0.70 & 0.70 & 0.70 & 0.70 \\
\hline
\end{tabular}

* highest precipitation value corresponding to a consecutive period of 24 hours; ** value between the observation hours of precipitation.

From the data of maximum daily rainfall (Table 3) and the disaggregation coefficients (Table 4 ), the relations of rainfall-duration-frequency (RDF) were obtained. Therefore, equations representing intensity values, from the series using annual and partial duration were obtained (Table 5). The IDF relationships obtained in this study represent a gain of information for hydrological studies of the region, since they have no expiration date for the duration of $5 \mathrm{~min}$, whereas the in equation presented by GOULART et al. (1992), the lower duration limit is $30 \mathrm{~min}$. Additionally, the IDF relationships presented in Table 5 refer to a period of 88 years (1921 to 2008), while that of GOULART et al. (1992) represents a shorter period of time (31 years, from 1961 to 1990).

TABLE 5. Intensity-duration-frequency equations (IDF) obtained starting from the adjustment of the values of the annual series and partial duration, in the period from 1921 to 2008 of Pelotas-RS.

\begin{tabular}{cc}
\hline Series & IDF Equation \\
\hline Annual & $I=\frac{5684.1 \operatorname{Tr}^{0.1043}}{(t+52.2271)^{1.008}}$ \\
Partial Duration & $I=\frac{3365.5 \operatorname{Tr}^{0.1717}}{(t+53.2504)^{0.9639}}$ \\
\hline
\end{tabular}

I - Average maximum intensity of rainfall $\left(\mathrm{mm} \mathrm{h}^{-1}\right) ; \mathrm{Tr}-$ Return period (years); $\mathrm{t}$ - rainfall duration (min). 
Analyzing the results presented in Table 6, the intensity values obtained from the estimated IDF by using the partial duration series and annual historical values do not differ from the maximum intensities for return periods of $2 ; 5$ and 10 years, since the calculated values of the " $t$ " statistics for the slope $\left(\beta_{1}\right)$ were higher than the critical " $t$ " value for an $\alpha$ level of $1 \%$ probability. Moreover, for the linear coefficient $\left(\beta_{0}\right)$, the statistic values were lower than the critical value. According to ZANETTI et al. (2009), the importance of statistical analysis related to linear and angular coefficients lies in the determination of the slope of the regression line, given by $\beta_{1}$.

TABLE 6. Results of the linear fit $\left(Y=\beta_{0}+\beta_{1} X\right)$ and correlation coefficient $(r)$, obtained among the values of maximum intensities of rain $\left(\mathrm{I}_{\max }\right)$ historical and obtained them starting from the series of partial and annual duration of the city of Pelotas-RS, for the periods of return of $2 ; 5$ and 10 years.

\begin{tabular}{cccccc}
\hline $\operatorname{Tr}$ (years) & $\beta_{0}$ & $\beta_{1}$ & $\mathrm{t}\left(\beta_{0}\right)$ & $\mathrm{t}\left(\beta_{1}\right)$ & $\mathrm{r}$ \\
\hline \multicolumn{5}{c}{ Partial Duration $\mathrm{I}_{\max } v s$. Historical $\mathrm{I}_{\max }$} \\
\hline 2 & 2.9578 & 0.8014 & 0.8871 & 10.72 & 0.9831 \\
5 & 2.7596 & 0.6532 & 0.9636 & 14.51 & 0.9906 \\
10 & 1.5138 & 0.7209 & 0.6382 & 20.28 & 0.9952 \\
\hline 2 & 2.8251 & 1.0980 & 0.6603 & 11.45 & 0.9851 \\
5 & 2.9123 & 0.8521 & 0.8035 & 14.95 & 0.9912 \\
10 & 1.1523 & 0.8973 & 0.4075 & 21.17 & 0.9956 \\
\hline
\end{tabular}

$\beta_{0}$ e $\beta_{1}$ : linear and angular coefficients of the linear fit; $\mathrm{t}_{\mathrm{ab}(1 \%)}=4.60$

BEN-ZVI (2009) estimated IDF relationships for Israel using a partial duration series and pointed out improvement in the prediction of maximum rain intensity values, when the number of partial duration was employed, compared to intensity values estimated from the annual series. The author attributed this result to the smaller variance of the data contained in the series of partial duration compared to the annual series, and concluded on the feasibility of using partial duration series to estimate IDF relationships. For the city of Pelotas, despite the fact that the variance of the intensities in the partial duration series was lower $\left(518.61 \mathrm{~mm}^{2}\right)$ in relation to the annual series $\left(1,014.83 \mathrm{~mm}^{2}\right)$, the results of the " $t$ " test (Table 6) show that there was no improvement in predicting the intensity values when using the partial duration series compared to the annual series.

According to GRIMALDI et al. (2011), for practical purposes the partial duration and annual series do not differ much from each other, except for low return periods. It is observed that the results of the " $t$ " test showed no significant difference, however when we analyze the percentage differences for each return period, e.g., for the return period of 10 years in which most hydrological projects are designed (DAMÉ et al., 2005), the values of hourly intensities found when using the annual series and partial duration were, respectively, $62.01 \mathrm{~mm} \mathrm{~h}^{-1}$ and $52.34 \mathrm{~mm} \mathrm{~h}^{-1}$. For hydraulic structures, if the return period used for the project is 100 years, the figures are $78.84 \mathrm{~mm} \mathrm{~h}^{-1}$ and $77.72 \mathrm{~mm} \mathrm{~h}^{-1}$, respectively. In case of 10 years return period, the percentage difference of the intensity values is around $16 \%$, whereas for $\mathrm{Tr}=100$ years, this figure is minimized to $1.5 \%$. Thus, it is possible to observe that there is indication that partial duration values can be used for return periods exceeding 10 years, which percentage differences are smaller.

It should be noted that in the present study, the formation of partial duration series was obtained from 88 years of data that, according to WILKEN (1978), contradicts the basic assumption of the use of partial duration series, in which the number of years of observations is less than 12 years. 


\section{CONCLUSIONS}

For the rainfall data analyzed, there was no information gain in terms of relative intensityduration-frequency (IDF) when using the partial duration series with the base value established by GOULART et al. (1992), compared to the series of historical records.

Considering the return periods of up to 10 years, the intensity values obtained from the use of the partial duration series to estimate IDF relationships showed differential percentages of around $16 \%$, when compared to the historical values. For return periods of, or greater than 100 years, there were no relevant differences.

\section{REFERENCES}

ARON, G.; WALL, D.J.; WHITE, E.I.; DUNN, C.N. Regional rainfall intensity-duration-frequency curves for Pennsylvania. Water Resources Bulletin, Salt Lake City, v.23, n.2, p.479-485, 1987.

BACK, A.J. Relações entre precipitações intensas de diferentes durações ocorridas no município de Urussanga, SC. Revista Brasileira de Engenharia Agrícola e Ambiental, Campina Grande, v.13, n.2, p.170-175, 2009.

BACK, A.J. Relações intensidade-duração-frequência de chuvas intensas de Chapecó, Estado de Santa Catarina. Acta Scientiarum Agronomy, Maringá, v.28, n.4, p.575-581, 2006.

BEGUERÍA, S. Uncertainties in partial duration series modelling of extremes related to the choice of the threshold value. Journal of Hydrology, Amsterdam, v.303, n.1-4, p.215-230, 2005.

BELL, F.C. Generalized rainfall-duration-frequency. Journal of Hydraulics Division. American Society of Civil Engineers, New York, v.95, n.1, p.311-327, 1969.

BEN-ZVI, A. Rainfall intensity-duration-frequency relationships derived from large partial duration series. Journal of Hydrology, Amsterdam, v.367, n.1-4, p.104-114, 2009.

BORGA, M.; VEZZANI, C.; FONTANA, G.D. Regional rainfall depth-duration-frequency equations for an Alpine Region. Natural Hazards, Dordrecht, v.36, p.221-235, 2005.

BRUSA, L.C. Aprimoramento estatístico da regionalização de vazões máximas e médias: aplicação a bacias hidrográficas do Rio Grande do Sul e Santa Catarina. 2004. 188 f. Tese (Doutorado em Engenharia de Recursos Hídricos e Saneamento Ambiental) - Universidade Federal do Rio Grande do Sul, Porto Alegre, 2004.

COWPERTWAIT, P.S.P. A spatial-temporal point process model of rainfall for the Thames catchment, UK. Journal of Hydrology, Amsterdam, v.330, p.586-595, 2006.

DAEE-CETESB. Departamento de Água e Energia Elétrica. Companhia de Tecnologia de Saneamento Ambiental. Drenagem urbana: manual de projeto. São Paulo: DAEE-CETESB, 1979. $476 \mathrm{p}$.

DAMÉ, R.C.F.; TEIXEIRA, C.F.A.; LORENSI, R.P. Simulação de precipitação com duração horária mediante o uso do modelo Bartlett-Lewis do pulso retangular modificado. Revista Brasileira de Agrociência, Pelotas, v.13, n.1, p.13-18, 2007.

DAMÉ, R.C.F.; TEIXEIRA, C.F.A.; MOURA C.; MACHADO, R.; BESKOW, S. Análise do impacto de um evento de precipitação ocorrido na cidade de Pelotas - RS. Revista de Ciências Agro-Ambientais, Alta Floresta, v.3, p.15-25, 2005.

DAMÉ, R.C.F.; TEIXEIRA, C.F.A.; TERRA, V.S.S. Comparação de diferentes metodologias para estimativa de curvas intensidade-duração-freqüência para Pelotas - RS. Engenharia Agrícola, Jaboticabal, v.28, n.2, p.245-255, 2008.

DAMÉ, R.C.F.; TEIXEIRA, C.F.A.; TERRA, V.S.S.; ROSSKOFF, J.L.C. Hidrograma de projeto em função da metodologia utilizada na obtenção da precipitação. Revista Brasileira de Engenharia Agrícola e Ambiental, Campina Grande, v.14, n.1, p.46-54, 2010. 
GOULART, J.P.; MAESTRINI, A.P.; NEIBEL, A.L. Relação intensidade-duração-frequência de chuvas em Pelotas, RS. Revista Brasileira de Meteorologia, Pelotas, v.7, n.1, p.543-552, 1992.

GRIMALDI, S.; KAO, C.; CASTELLARIN, A.; PAPALEXION, S.M.; VIGLIONE, A.; LAIO, F.; AKSOV, H.; GEDIKLI, A. Statistical Hidrology. Treatise on Water Science, Oxford, v.2, p.479517,2011

GROPPO, J.D.; MORAES, J.M.; BEDUSCHI, C.E.; MARTINELLI, L.A. Análise de séries temporais de vazão e precipitação em algumas bacias do estado de São Paulo com diferentes graus de intervenções antrópicas. Geociências, São Paulo, v.24, n.2, p.181-193, 2005.

LONGO, A.J.; SAMPAIO, S.C.; SUSZEK, M. Equação de chuvas intensas e precipitação provável para o município de Cascavel, PR. Revista Varia Scientia, Cascavel, v. 6, n. 11, p.119-127, 2006.

MADSEN, H.; RASMUSSEN, P.F.; ROSBJERG, D. Comparison of annual maximum series and partial duration series methods for modeling extreme hydrologic events. 1. At site modeling. Water Resources Research, Saint Louis, v.33, n.4, p.747-757, 1997.

MELLO, C.R.; SILVA, A.M. Métodos estimadores dos parâmetros da distribuição de Gumbel e sua influência em estudos hidrológicos de projeto. Irriga, Botucatu, v.10, n.4, p.318-334, 2005.

OLIVEIRA, L.F.C.; CORTÊS, F.C.; WEHR, T.R.; BORGES, L.B.; SARMENTO, P.H.L.; GRIEBELER, N.P. Intensidade-duração-frequência de chuvas intensas para localidades no Estado de Goiás e Distrito Federal. Pesquisa Agropecuária Tropical, Goiânia, v.30, n.1, p.13-18, 2005.

ROBAINA, A.D.; PEITER, M.X. Modelo de desagregação e de geração de chuvas intensas no RS. In: CONGRESSO BRASILEIRO DE ENGENHARIA AGRÍCOLA, 21.; SIMPÓSIO DE ENGENHARIA AGRÍCOLA DO CONE SUL, 1., 1992, Santa Maria. Anais... Santa Maria: Sociedade Brasileira de Engenharia Agrícola, 1992. p.746-753.

RODRIGUES, R.A.; SANTOS, R.S. Estudo de tendência climática na série temporal de precipitação pluviométrica em Araguari (MG). Revista Geográfica Acadêmica, Manaus, v.1 n.1, p.20-27, 2007.

SANSIGOLO, C.A. Distribuições de extremos de precipitação diária, temperatura máxima e mínima e velocidade do vento em Piracicaba, SP (1917-2006). Revista Brasileira de Meteorologia, Piracicaba, v.23, n.3, p.341-346, 2008.

SILVA, J.M.A.; PRUSKI, F.F.; SILVA, D.D.; CECÍLIO, R.A. Metodologia para obtenção do hidrograma de escoamento superficial em encostas e canais. Parte I: Desenvolvimento e avaliação. Engenharia Agrícola, Jaboticabal, v.26, n.3, p.695-703, 2006.

SILVEIRA, A.L.L. Equação para os coeficientes de desagregação de chuva. Revista Brasileira de Recursos Hídricos, Porto Alegre, v.5, n.4, p.143-147, 2000.

SOUZA, A.M.; GEORGEN, R.; FERRAZ, S.E.T. Previsão de precipitação e temperatura em Santa Maria por meio de um modelo estatístico. Ciência e Natura, Santa Maria, v.31, n.1, p.49-64, 2009.

SVENSSON, C.; CLARKE, R.T.; JONES, D.A. An experimental comparison of methods for estimating rainfall intensity-duration-frequency relations from fragmentary records. Journal of Hydrology, Amsterdam, v.341, p.79-89, 2007.

WILKEN, P.S. Engenharia de drenagem superficial. São Paulo: CETESB, 1978. 447 p.

ZANETTI, S.S.; OLIVEIRA, V.de P.S.; SOUSA, E.F.; ALMEIDA, F.T.; SUGAWARA, M.T.; SILVA, J.M.A. Modelagem hidrológica em microbacia hidrográfica Parte II: Teste do modelo HidroBacia. Revista Brasileira de Engenharia Agrícola e Ambiental, Campina Grande, v.13, n.4, p.435-442, 2009. 